\title{
Gender East and West: Transnational Gender Theory and Global Marketing Research
}

\author{
Katherine Sredl \\ Loyola University Chicago, ksredl@luc.edu
}

Follow this and additional works at: https://ecommons.luc.edu/business_facpubs

Part of the Marketing Commons, Migration Studies Commons, Quantitative, Qualitative, Comparative, and Historical Methodologies Commons, Social and Cultural Anthropology Commons, and the Women's Studies Commons

Author Manuscript

This is a pre-publication author manuscript of the final, published article.

\section{Recommended Citation}

Sredl, K. C. (2019). Gender East and West: Transnational Gender Theory and Global Marketing Research. In S. Dobscha (Ed.), Handbook of Research on Gender and Marketing (pp 45-62). Cheltenham, UK: Edward Elgar Publishing.

This Book Chapter is brought to you for free and open access by the Faculty Publications and Other Works by Department at Loyola eCommons. It has been accepted for inclusion in School of Business: Faculty Publications and Other Works by an authorized administrator of Loyola eCommons. For more information, please contact ecommons@luc.edu.

\section{c) (i) $\ominus$}

This work is licensed under a Creative Commons Attribution-Noncommercial-No Derivative Works 3.0 License. (C) Edward Elgar Publishing 2019 


\section{Gender East and West: transnational gender theory and global marketing}

research

Katherine C. Sredl

Cite:

Sredl, K. C. (2019). Gender East and West: Transnational Gender Theory and Global Marketing Research. In S. Dobscha (Ed.), Handbook of Research on Gender and Marketing (pp 45-62). Cheltenham, UK: Edward Elgar Publishing.

ISBN: 9781788115377 https://www.e-elgar.com/shop/handbook-of-research-on-gender-andmarketing

\section{INTRODUCTION}

From the 1946 constitution on, women in Yugoslavia had equal citizenship, voting rights, equality in employment and political office, the right to divorce, equality in education, reproductive rights, and protections as mothers. Women were expected to work, from participating in the Anti-Fascist Movement to rebuilding the infrastructure after World War II to factory work, from the mid-1950s on (Centre for Women's Studies Zagreb and Iveković, 2002). At home, they were expected to take care of the house and the family, and their role was often assumed to be to care for the continuation of the nation in a time of foreign domination (Funk, 2004). In 1963, Betty Friedan wrote The Feminine Mystique, symbolically launching the Second Wave feminist movement in the United States. Second Wave feminists challenged the idea that women "belonged" in the home, where they rarely had individual rights, and men "belonged" in the public sphere, which they were to dominate (Funk, 2004). In 1972, the Equal Rights Amendment passed the US Congress, yet was never ratified by the required 38 states in time to become the law of the land. The 1978 conference, Drugarica žena-žensko pitanje: novi pristup? 
(Comrade Woman-The Woman's Question: A New Approach), held in Belgrade, was a seminal event in feminist thought in Yugoslavia and in Central and Eastern Europe. It included participants from Zagreb, Belgrade, Sarajevo, and Western Europe. Yugoslav feminists argued for a consideration of equality in the private sphere and the "full emancipation of humanity," (Zaharijević, 2015, p. 96). For them, equality included the division of labor in the home and a consideration of domestic abuse as illegal, challenging the state to intervene in the life of the family (Zaharijević, 2015).

Western European feminists critiqued the philosophy of Yugoslav feminists, mostly for not advocating for individual rights. The tension between the two perspectives revealed the possible lack of understanding on the part of Western European feminists about the realities of Yugoslavia: that their critique of the lack of consideration of the domestic space was both a critique of living with patriarchy in private life and a veiled critique of the system that had overlooked the private sphere. Domestic violence laws were non-existent in Yugoslavia. Perhaps these Western feminists were anticipating a more universalist female experience, or a feminist political theory based on similar traditions of political thought and structure as in the US or Western Europe (Funk, 2004).

After the Cold War, this dynamic of a lack of understanding of local circumstances, or an assumption of a universal gendered experience, often continued in new iterations of global feminist studies. With a few notable exceptions, most global feminist theory tends to originate in the First World and focuses on development, especially in the form of individual micro-finance, in the Third World (Ghodsee, 2004). The post-socialist space is often overlooked in contemporary feminist thought, especially related to gender and marketing, as it does not fit into this neat development formula (Ghodsee, 2004). Many post-socialist spaces, such as Croatia, are 
European Union members. Others, such as Georgia, are places where questions of institutionalizing democracy are relevant, but the concerns of the Least Developed Nations (LDNs), such as infant and maternal mortality, are not relevant.

In addition to the question of post-socialist spaces not fitting the development paradigm, there is a difference in feminist philosophy between the United States and Central and Eastern Europe, and between Central and Eastern Europe and Russia (Funk, 2004). Given the differing political philosophies and roles of the state in society in the US and in the states that make up the post-socialist space, feminism in the US tends to focus on the individual rights of women. However, in post-socialist spaces, feminism tends to focus on the rights of women as a group (Funk, 2004). The difference in perspective puts into relief the role of the state in women's lives.

In this chapter, I offer an approach for meeting the goal of improving women's lives through the critical analysis, cultural analysis, and transformative agenda of gender and marketing research. My view brings a transnational perspective into current global gender and marketing studies, calling for local engagement with feminist scholars and activist movements. A transnational lens also understands and applies the contributions of feminist thought from this region, especially the focus on the changing role of the state and emerging gendered inequities in the era of neoliberal globalization. In this chapter, I argue for blending a transnational gender research perspective with current global gender and marketing perspectives, especially the transformative consumer research perspective (Heine et al., 2016). My goal is to bring the postsocialist space and other spaces that tend to not fit the Third/First World binary, into the fold of global gender and marketing research.

\section{THEORY}


This literature review first addresses transnational approaches to gender studies. The focus then moves to the history of the women's movement in Yugoslavia and Croatia. I use this context to argue for the benefits of including transnational approaches to gender and marketing research: they allow for global gender and marketing research to focus on questioning the dwindling role of the state, labor, and civil society in solving problems faced by women. Transnational perspectives also include tracking from multiple locations of academic and political engagement. This section concludes by discussing recent studies of gender and marketing in the developing world (sometimes also called the Third World or LDNs) in the consumer behavior discipline, and presents ways that a transnational approach could be applied to extend current frameworks (Ardrey, Pecotich, and Shultz, 2006; Hein et al., 2016).

\section{TRANSNATIONAL GENDER STUDIES}

Transnational is a term that has been applied in various interrelated disciplines, from gender studies to sociology to literature, to describe scholarship, activism, and a method of research (Nadkarni, 2017). Transnational gender studies evolved in reaction to the predominance of research from the economically developed, Western, Northern Hemisphere, on Non-Western, Southern Hemisphere, Third World contexts. This First World/Third World research dynamic has been criticized for assuming that a global "sisterhood" exists and for overlooking the diversity of women's experiences and feminist thought across the globe. Anthologies such as Sisterhood Is Global are criticized by transnational feminist scholars as exemplars of the "sisterhood" cultural feminist perspective for overlooking questions of class, economic structures, race, local feminist thought, and nationality in global scholarship (Morgan, 1984; Trimberger, 1986; Wilson, 1986). A related critique of the global "sisterhood" or cultural 
feminism approach in a global context is that, while non-governmental organizations (NGOs) and non-profit micro-enterprises have brought improvement to the lives of women, especially in the developing world, they rarely tend to challenge the global and local social, political, and economic institutions that enable inequalities (Ghodsee, 2004).

Many critiques of issues of location in gender studies came from scholars in the Northern Hemisphere, with ties to the so-called Third World. Their work - together with scholars who challenged the idea of a singular perspective of women's lives in the 1980s - pointed out the ways that the cultural feminism approach overlooked the diversity of women's experiences of race, class, and sexuality. The United Nations Decade for Women (1976-1985) and the rise of related NGOs and transnational feminist networks (TFNs; Moghadam, 2005) created ties between women of color in the United States and women in the so-called Third World. These ties, Suchland (2011) argues, grew stronger as these scholars critiqued US domestic welfare policy from the position that it mirrored US foreign policy in Latin America, Africa, and Southeast Asia that maintained "neocolonial and nondemocratic arrangements" (Suchland, 2011, p. 840) in place.

Seminal transnational feminist anthologies such as Scattered Hegemonies: Postmodernity and Transnational Feminist Practices (Grewal and Kaplan, 1994) call for scholarship and activism that address "the radical changes in global economic structures that have occurred since the middle of this century. If the world is currently structured by transnational economic links and cultural asymmetries, locating feminist practices within these structures becomes imperative" (Grewal and Kaplan, 1994, p. 3). Grewal and Kaplan (1994) also call for transnational scholarship that moves between multiple locations in which scholars are embedded both politically and academically. 
In spite of the in-betweenness of the post-socialist space, or perhaps because of it, scholars who track back and forth between post-socialist states and US universities have argued for opening up the Third World/development paradigm to include the contributions of transnational scholarship. Such contributions include complicating assumptions of a global normative subjectivity of women's experiences, and a consideration of local feminist philosophy in Central and Eastern Europe, which tends to be less organized around paradigms of individualism and the social contract than US feminism, and more around notions of anticolonialism and group rights (Funk, 2004). Although both the individualist and anti-colonialist paradigms are questioned by their respective feminist movements, they are an important starting point of difference (Funk, 2004). Transnational scholars also question the ways that global market structures and logics create new inequalities and replicate existing hierarchies in emerging and so-called developing markets (Ghodsee, 2004; Suchland, 2011; Sredl, 2018).

The organization of area studies in US universities during the Cold War tended to keep research on gender in Russia and Eastern Europe separate from gender scholarship on the Caribbean or the so-called Third World. As a consequence, gender scholars from or of this region were left somewhat outside the global gender discourse. Furthermore, scholarly thought in the disciplines of Slavic or Soviet Studies during the Cold War tended to think that power worked in dictatorships through selves that were split into two: a public self that accommodated power and a private one that resisted, leaving little room for understanding women's lived experiences outside of the dichotomy approach. Recently, scholars have demonstrated that power worked discursively in the past, often through everyday practices (Luthar and Pušnik 2010; Sredl, 2018). This scholarly location outside the First World/Third World dichotomy tended to affirm the exclusion of the socialist and post-socialist space from the global gender debate. 
Philosophical assumptions about how power worked also kept gender at the margins of research on these regions (Ghodsee, 2004; Suchland, 2011).

To illustrate the heterogeneity of the post-socialist space, how the space differs from the Third World, and how this difference plays out in United Nations' categories and programs and related scholarship, I offer the following comparison of UN categorization of and activity in the so-called Third World and the post-socialist space. The UN categorizes countries into LDNs, based on criteria such as economic vulnerability indicators - including population size and birth rate, remoteness, share of agriculture in GDP, and instability of agricultural production - and human assets indicators such as maternal mortality ratio, under-five mortality rate, and adult literacy rate (United Nations Economic Analysis \& Policy Division [UNEPD], 2018). In LDN countries such as Cambodia, for example, programs focus on lowering the under-five mortality rate (UNEPD, 2018). By contrast, the UN is engaged with the governments of Georgia and other post-socialist states in the Caucasus, for example, in the areas of democratic governance and environment and energy (United Nations Development Programme [UNDP] 2018). The UNDP office in Croatia closed on 31 December 2017, after 20 years of focusing on Sustainable Development Goals (UNDP, 2017). Croatia ranks in the Very High Human Development group in the 2016 UNDP Human Development Report, along with the United States (UNDP 2016). Now that some of the differences within post-socialist spaces and between this space and the Third World are highlighted, what remains to consider is how a marketing and gender research topic would look, from the transnational gender research perspective.

Migration studies offers an example of transnational gender scholarship that questions assumptions about global economic structures and the universal subjectivity of women and includes voices from the periphery. Andall (2000) complicates the EU migration narrative by 
pointing out how gendered migration is seen in states such as Italy as a solution to the state's demographic crisis: however, Italy does not grant full citizenship rights to female migrant laborers, who are often women of color. Andall (2000) also points out that Italian feminists are unable to see migrants of color as anything other than domestic help and, therefore, fail to help them. A key difference between the transnational and the "global sisterhood" perspective, as evident in Andall's work, is the ability to complicate the relationship between groups of women, based on privileges of nation, race, and class, both in the local and global context (Andall, 2000). As this example shows, engagement with local gender scholarship and activism helps place research questions at the nexus of local and global market dynamics, thereby bringing local perspectives on gender into transnational thought (Grewal and Kaplan, 1994). In the next section, I discuss the history of feminist thought and activism in Croatia.

\section{FEMINIST THOUGHT IN YUGOSLAVIA AND CROATIA}

During the immediate post-World War II period, from 1945 to 1952, official Yugoslav feminism focused on women fighting “alongside men" in the Antifascist Women's Front (AFŽ) during the partizan (partisan, communist and anti-Axis) guerilla fighting during World War II. The best embodiment of the ideal post-war Yugoslav woman was Jovanka Broz, the wife of dictator-forlife Josip Broz Tito. Jovanka fought as a Lt. Colonel in the partizan movement and was a political partner to her husband. From the 1946 constitution on, women in Yugoslavia had equal citizenship, voting rights, equal employment rights, the right to legal divorce, the right to political office, protection as mothers, and reproductive rights. While contraception was not readily available in the entire period of Yugoslavia (1946-1991), abortion was made legal in Yugoslavia in 1952 (Zaharijević, 2015). The post-war period through the mid-1950s was 
characterized by industrialization and urbanization (Sredl, 2007). Women were included as equals in the volunteer labor of the reconstruction and industrialization process that took place in the immediate post-war period (Centre for Women's Studies Zagreb and Iveković, 2002).

In 1948, Tito broke with Stalin, and began a process of reforming or de-Stalinizing the Communist Party of Yugoslavia. Yugoslavia was a leader in the Non-Aligned Movement, which started in 1956 on the Brijuni Islands on the Adriatic Sea. While the state never turned away from its partizan narrative, in the 1953, 1963, and 1974 constitutions, the state sought legitimacy through an opening of the system. In the constitution of 1953 and the post-constitution reforms, the Yugoslav state looked to women to embody the new gender and class equality through education and the workforce, which included logics such as worker's self-management. The 1963 constitution further reduced state management of enterprises and expanded civil rights. The 1974 constitution decentralized federal power and offered some new rights, in response to the Croatian Spring.

Women's employment in the public sector and involvement in self-management were ways to promote their status as equals. For example, in Croatia, in 1953, women represented 24 percent, and by 197035 percent, of the public sector workforce (SG FNRJ, 1955, 86). That figure rose to 38 percent in 1975, to 39 percent in 1980, and to 42 percent in 1985, reaching 42 percent in 1991, according to official statistics. Women's participation in higher education continued to grow as a percentage of all higher education graduates as well. In 1970, 42 percent of university graduates were women, in 1985 the rate was 49 percent, and by 199056 percent of all university graduates were women (see SG SRH statistics in Sredl and Renko, 2009). However, these advances in education and employment in the formal economy, as represented in statistics, tended to reflect the experiences of women in cities in Yugoslavia, as opposed to rural 
areas (Cockburn, 1998). In the geopolitical context of Yugoslavia as a non-aligned state in the Cold War, these statistics and ideologies allowed the state to demonstrate that women in Yugoslavia had equal employment rights - while the Second Wave in the US was fighting for equal employment rights - and lived better than women in the East (Sredl, 2018).

After the Croatian Spring in 1971, the state used some changes to the Yugoslav constitution of 1974 - and a position of tolerance of some symbols of dissent or criticism in popular culture such as music - as signs of its commitment to humane socialism. Outside of the AFŽ rhetoric, a feminist movement in Yugoslavia - in fact, the only women's movement in Eastern Europe outside official state organization - began in Zagreb and Belgrade in the mid1970s, at the grassroots level, among journalists and scholars. The 1978 conference, Drugarica žena-žensko pitanje: novi pristup? (Comrade Woman-The Woman's Question: A New Approach), held in Belgrade, was a crucial event in the feminist movement in Yugoslavia and in Central and Eastern Europe. The conference included feminists from Zagreb, Belgrade, Sarajevo, and Western Europe (Drakulić, 1992; Pavlovič, 1999; Zaharijević, 2015).

Given the struggle of the AFŽ for the right of the state to exist, and the constitutions of 1946 and 1953, women had rights as workers and voters, along with protection as mothers. Thus, the issues of Western feminism at the time, such as fighting a patriarchal state for equal rights at work and in politics, did not overlap with the context and structure of socialist citizenship in Yugoslavia. The main feminist critique from Zagreb and Belgrade was that the Yugoslav ideology of self-management and its reform-oriented constitutions, given their focus on the means of production, had yet to liberate the private sphere. Yugoslav feminists linked the private sphere to ideology and politics by arguing that it had a direct influence on the functioning of selfmanagement (Rihtman-Auguštin, 1980, p. 85). 
Leinert Novosel (1999) argues that Yugoslavia brought women into public life through working outside the home and participation in party and state politics. Leinert Novosel (1999) also suggests that these gains and policies did not, in spite of 50 years of enforcement, lead to new assumptions that women and men were equal in their capabilities to make decisions and to operate at the level of decision-making in public life, from politics to the economy. Despite official statistics, and the elevation of women in the one-party system, generally speaking, women were not final political or economic decision-makers.

In Yugoslavia, neither feminists nor the majority of women interpreted work as independence for women; however, early Second Wave feminists (mostly white, middle- and upper-middle-class) in the United States, saw work as independence from dependence on wageearning husbands (Friedan, 1963). Another effect of low wages in Yugoslavia was that divorce, while legal, presented the problem of living on one low wage, usually with dependent children. There was no option of staying at home while a spouse worked, since full employment was part of the system. Jobs and careers were not a matter of choice: a woman was assigned a job in the field that needed employees. In spite of guaranteed jobs and the focus on labor, unemployment rates were high. When the state opened its borders and relaxed emigration regulations, especially for the increasingly highly educated workforce, employment abroad and remittances home offered a quasi-solution to the problem of unemployment; by the early 1970s, about 20 percent of the labor force was working abroad (Woodward, 1995). The gender dynamics of labor migration in Yugoslavia is a relatively under-researched topic, with a few exceptions (Svanberg, 2011). Likewise, in spite of official rhetoric of equality in education, labor, and politics during the Yugoslav era, women were still seen as "naturally" more fit for work in the private sphere of 
the home (Leinert Novosel, 1999). Cultural norms of patriarchy meant women did the work at home, and men made the decisions for all of the family members (Cockburn, 1998).

Yugoslav feminists argued that socialist goals in Yugoslavia could not be achieved if women's concerns were subsumed to the goal of class equality (Despot, 1981). A related critique by Yugoslav feminist thought was that women had rights as workers and were protected as mothers, yet men had rights as workers but not as fathers: the ideology was reductive (Einhorn, 1993). The AFŽ fought for the rights of the state to exist; the subsequent fight for equality was not against the state for women's rights, as in the West (Zaharijević, 2015). For Yugoslav feminists of the 1970s and 1980s, the goal was the "full emancipation of humanity" (Zaharijević, 2015, p. 95). For example, a goal of the feminist movement in Yugoslavia was for the state and judiciary to address domestic abuse. In the tradition of political thought in Croatia and Yugoslavia, at that time, rights existed for the group, but not for the individual (Funk, 2004). Funk has also argued against the Western view of the public/private divide as part of life in Central and Eastern Europe during socialism (2004). Funk suggests that the home was an area of political interest: for example, abortion and divorce were legal; however, some issues related to the home, such as violence against women, were not an issue of political concern in most socialist states in Central and Eastern Europe (Funk, 2004). Hence, the argument against domestic violence needed to be framed as being good for the state, as opposed to a representation of notions of individual rights or women's rights, which the state claimed had already been granted in the constitution.

During the Cold War, for example, in the tensions between Yugoslav and Western feminists at the 1978 Drugarica conference, Western feminists critiqued Yugoslav feminists for not framing rights as an individual issue. Outside the region, critical perspectives overlooked the 
important factors that framed Yugoslav feminism and its legacy: attention to the philosophy of rights of the group, the politics of social class, and gender equality laws and their specific logics as they related to private life (Woodward, 1995; Funk, 2004; Ghodsee, 2004).

In sum, there were two major periods of organization of feminist thought in Yugoslavia: during and immediately after World War II, and the 1970s and 1980s. Generally speaking, the state used women's rights in two, sometimes contradictory, ways. The state sought to delegitimize feminism, as feminism's premise of inequality challenged the notion that the state had established equality. The state framed Western feminism as individualistic, bourgeois, and the opposite of official, local feminism. Yet the state also used women's partizan activity to make legitimate the origins of the state and its promise of women's equality. The state also used its ideology and policy commitments to advance women's education, labor force participation (especially in the public sector and the textile industry), and political participation to legitimate its claims to and accomplishments in creating a society of equal workers through socialist selfmanagement; for most urban women, and for nearly all rural women, the lived experience of these laws was vastly different than the ideology or averages presented in state statistics. Feminists in Yugoslavia argued for women's rights as equal members of society, and for feminist concerns to be treated as an important component of achieving socialist goals.

The 1990s were characterized by armed conflict, privatization, and state-building across most of the post-Yugoslav space. Women bore the brunt of the wars in the form of lost husbands, sons, and fathers, in addition to the use of rape as a weapon of war: feminists mobilized against rape as a tool of war (Nikolić-Ristanović, 2000). In this period, the paradigm of citizenship shifted from the Yugoslav model to citizenship based on ethnic belonging to the nation-state and its new borders. As a result of the emphasis on the state, a transnational understanding of 
feminism emerged in Croatia, Serbia, and other states in the post-Yugoslav space, in which feminism became the "space of citizenship" for many of the feminist activists of the 1970s and 1980s (Zaharijević, 2015, p. 96).

Feminism as a space of citizenship was especially important as a critique of the change in the gender make-up of the political institutions of the new states: most politicians in the new states were men, unlike in the Yugoslav era. Feminism as citizenship also critiqued the new borders, drawn by new, nationalist (male) leaders, without an official voice from the people living in these states. In the 1990 elections in Croatia, of the 80 people elected, only three were women; during the Yugoslav era, women held about 20 percent of elected positions (Špehar, 2012). Culturally and politically, the new states saw women's roles as giving birth to the new nation-state and ensuring its future by being a good mother; while women's roles during socialism implied keeping the nation alive during colonial domination, it also included work and political participation (Zaharijević, 2015).

Likewise, the post-war period was characterized by a political and economic backlash against women's advances in politics and in labor, especially in the public sphere, which had been a site of female employment. Bonfiglioli has noted the devastation caused by privatization and deindustrialization in the case of the textile industry in the post-Yugoslav space as especially challenging to women, as this industry employed mostly women in the Yugoslav era (2015). In the 1990s, a result of deindustrialization and the ideology of the socialist woman as a motherworker was the rise of the idea of the woman as a mother who does not work.

The post-war period of the 2000s was marked by democratic state-building, a round of intense privatization, and gender mainstreaming in the political sphere. The economic crisis of 2008 - followed by the accession of Croatia to the EU in 2013 - brought new austerity and 
pressures of neoliberal globalization. Sredl (2018) has demonstrated that the logics of neoliberalism in the 2000s socially and economically marginalize women who were once exemplars of Yugoslav exceptionalism as factory workers. These women, after privatization, are working as house cleaners in Zagreb, due to the closing of factories. The new marketplace logic of neoliberalism valorizes women, especially young women, who can self-transform their bodies and their selfhood to be attractive to men and to employers in an era of autonomy and flexible work arrangements for the middle class. There can be a tendency in gender and marketing research on privatization to label those women who lost privilege during privatization as "left behind," or failing to adjust (Coulter, Price, and Feick, 2003). Sredl (2018), however, suggests a deeper inquiry into the logics of the old system and the logics of neoliberalism reveals that privatization maintained some privileges of the old system, yet created new inequalities of generation, gender, and class.

Gender mainstreaming as part of EU accession in 2013 brought laws guaranteeing gender equality. Yet the government of Croatia has tended to focus on post-crisis economic problems, such as unemployment; the unemployment rate in 2017 was 12 percent (estimated) (Špehar, 2012; Central Intelligence Agency, 2017). While gender equity laws have been institutionalized, women still face significant social and legal barriers to exerting their rights in equal employment and salaries, and in political participation; barriers may include administrative corruption and patriarchal gender norms (Špehar, 2012). Špehar argues that "gender equality laws and policy frameworks do not have any substantial effect on the daily lives of citizens" (2012, p. 373). Lower-wage work, such as care work and education, tends to be seen as women's work. Špehar demonstrates that women who "are subjected to rape ... abandon the idea of pressing charges for fear of social stigma or because they feel that the police, health, and judicial authorities lack 
experience in dealing with such cases” (2012, p. 373). Like Funk (2004), I suggest that the Croatian feminist context calls scholarly attention to conflicting and overlapping concepts of statehood, gender, nationhood, and belonging, as well as individual rights in an era of neoliberal individualism and the diminishing role of the state in society. In the next section, I address the current research on gender and marketing in the developing world and suggest ways that a transnational perspective can be applied to extend this scholarship.

\section{PRIOR RESEARCH ON GENDER AND MARKETING IN THE DEVELOPING WORLD}

Prior studies of gender and marketing in a global context have tended to theorize and to seek socially just solutions to the problems of development and inequality in the so-called Third World or Least Developed Countries (LDCs). Problems and solutions are often framed in accord with First World marketplace logics: micro-enterprise and empowerment are often seen as solutions. The emphasis on micro-enterprise and gender in marketing research in the LDCs might be an outcome of the UN emphasis on micro-finance, with women as clients, in developing countries such as Bangladesh, starting in 1975, as a means for poor households to increase their access to financial services and protect their families against vulnerability (see for example Binger, 2004). In this view, women entrepreneurs are considered a key link to improving societal welfare. The bank loans create opportunities that improve the lives of women and their families: women are instrumental to other goals. For example, Ardrey, Pecotich, and Shultz (2006) offer a culturally sensitive conceptual framework for understanding the dynamics of rural women's enterprise, access to capital, and societal welfare in Cambodia, Laos, and Vietnam (CLV); their work offers a deft analysis of access to capital as a gendered problem. Their work presents an in-depth engagement with the experiences of local women, and local 
women's history, which fits into the transnational emphasis on local activism and scholarly engagement (Ardrey, Pecotich, and Shultz, 2006; Grewal and Kaplan, 1994).

Ardrey, Pecotich, and Shultz (2006), taking a pro-social perspective to micro-finance in CLV, argue for marketing that is engaged in micro-enterprise in ways that focus on the relationship of micro-enterprise to socio-cultural environments, development challenges, and social goals. The authors address socio-cultural factors in their model of the socio-economic progress of entrepreneurial women and societal welfare in CLV, note that they are interrelated, and call for additional research on the dynamics of the model (Ardrey, Pecotich, and Shultz, 2006, p. 286). A transnational perspective, informed by the post-socialist space, offers insights that potentially extend the inclusive goals of the Ardrey, Pecotich, and Shultz (2006) model. One way of extending their important work on micro-finance in Vietnam might be questioning why individual women and not banks, NGOs, unions, or the state, assume the risk involved in a loan, and why questions of societal welfare are not addressed in the political sphere, but in the sphere of finance and private enterprise. Perhaps further research could more deeply engage with the reasons that women and not men are considered better risks for loans, and what those assumptions can tell us about gendered privileges and obligations to others, and how those cultural norms relate to micro-enterprise. For example, the authors suggest that some women may encounter tensions in family and community relations when they have "'too much" empowerment" (Ardrey, Pecotich, and Shultz, 2006, p. 288). Further research could explore cultural norms of gender and how they relate to notions of obligations to others, and its relationship to capital accumulation.

Research on gender, marketing, social justice, public policy, and the global North/South dynamic also fits in with transnational gender research. Hein et al. (2016) developed the 
Transformative Gender Justice Framework (TGJF) as a structure for developing public policy that provides transformative solutions to gender injustices. Among the many strengths of the TGJF are that it includes the structural, agentic, and socio-cultural forces that underlie gender injustice, as opposed to focusing on only structure, agency, or socio-cultural forces. For example, Hein et al. (2016) develop TGJF by linking the gender injustice of the sex trade in the Dominican Republic to the global inequalities of the North/South development dynamic that enable the sex tourism industry in the Dominican Republic to continue. They also suggest that NGOs and government agencies, in cooperation with locals, resolve injustice through providing services, while pointing out that NGOs are possibly complicit in injustice through the burden of empowerment and the individual responsibilization of ending injustice in the form of encouraging leaving sex tourism work, as opposed to offering other alternatives (Hein et al., 2016, p. 232). Another strength of TGJF is that it combines three lenses on solving inequality recognition theory, capabilities, and social justice - and encourages exploration of the tensions between the three perspectives (Hein et al., 2016).

The authors approach the study of gender in transformative consumer research (TCR) as primarily concerned with addressing gender injustices - of symbolism and representation, identity, and organization and institution - in the developed and developing world (Mick et al., 2012; Crockett et al., 2013; Hein et al., 2016). The work of Hein et al. (2016) is among the first major publications focused on gender justice in the tradition of TCR. The authors also theorize gender in TCR as taking an intersectional approach (Hein et al., 2016; Gopaldas, 2013). The TCR approach to gender and the TGJF approach to gender justice overlap with the theories, methods, and goals of transnational feminism, especially the focus on intersectionality and the inequalities in global and local development dynamics. 
A transnational approach could extend TGJF and TCR theory and methods by considering gender justice from the perspectives of the post-socialist space, where specific questions arise, related to: the conditions of individual citizenship, the weakening state, global neoliberal markets, the judicial enforcement of laws, and labor (Ghodsee, 2004; Sredl, 2018). Transnational feminism could also contribute its interest in local academic engagement, and the ways that geography produces exclusion: for example, the exclusion of academics and experiences from outside the global North/South divide (Ghodsee, 2004). While transnational feminism is not as explicitly concerned with social justice as TGJF is, it is similarly concerned with activism and with exposing inequalities (Hein et al., 2016).

An example of extending TGJF by adding a transnational view - specifically one informed by the post-socialist experience - to the work of Hein et al. (2016) in analyzing the case of sex workers in the Dominican Republic, would be to consider the role of a potential labor union in gendered social justice, in addition to NGOs. Extending the TGJF by using insights from transnational feminism, future research might include deeper questioning of women's relationship to the state and to their families as Hein et al. (2016) consider the regulation of tourism and sex tourism. Likewise, transnational feminism brings in questions of the role of the state, class, and labor, as well as the production of exclusion and the role of local academic engagement in activism, into further TGJF research.

\section{DISCUSSION AND DIRECTIONS FOR FUTURE RESEARCH}

This chapter sought to lay out the groundwork for transnational marketing and gender research, informed by the post-socialist space, with the intention that this theoretical framework can be used in conjunction with existing research and theories, such as the TGJF and pro-social work on 
marketing, gender, and lesser researched geographies more generally (Ardrey, Pecotich, and Shultz, 2006; Hein et al., 2016). A deep dive into transnational feminist thought, global gender research, and feminist thought in Croatia, starting in the period of Yugoslavia, was followed by a review of major articles on global gender and marketing. Comparing and contrasting these bodies of work reveals that questions of post-socialist feminism and transnational gender studies are focused on pointing out inequalities perpetuated by global neoliberalism, citizenship and women's obligations to the state and the self, the changing role of the state in providing a social safety net, labor, and philosophical understandings of gender and women's obligations in society, and local academic and activist engagement. Combining transnational feminist theories, methods, and goals and a TGJF framework and/or the framework developed in Ardrey, Pecotich, and Shultz (2006), can create new opportunities to research in ways that transform global consumer well-being.

Thus, a topic for further research that would bring together these perspectives would be the relationship between privatization and EU expansion and migration from rural regions of the new member states, leading to their economic devastation, with outcomes for public policy, gender, and marketing. For example, on the question of migration, the EU presents mobility partnerships as a development solution for problems of poverty, gender equality, and unemployment in the sending states. While most gender and migration research focuses on the impact of migration on the receiving states, and women's experiences of integration in the receiving states, often with the assumption of moving from traditional to modern cultures, transnational gender research questions how state and supra-state policies such as EU frameworks contribute to "furthering gender stereotypes and all associated negative consequences" in sending and receiving states (Chou, 2012, p. 12). 
Such a line of inquiry into emigration and migration would prove relevant for EU states such as Croatia, where emigration and labor migration from rural areas have increased since joining the EU in 2013. The statistics about gender and the movement of people - in 2017, 54 percent of emigrants from Croatia were men and 54 percent of internal migrants in Croatia were women; most internal migration is from the region of Slavonia to Zagreb - suggest that the areas of out-migration and emigration offer a promising area of research (Croatian Bureau of Statistics [CROSTAT], 2017). Some potential questions for exploration include: how questions of gender norms, class, access to capital, and labor markets influence these patterns, the socio-cultural outcomes for those left behind, the role of the state in the gendering of emigration and migration, the role of feminist activism and NGOs in the movement of people, ideas about gender, individualism and group obligations, and the economic and social outcomes for origin sites of emigration and migration.

\section{BIBLIOGRAPHY}

Andall, J. (2000). Gender, Migration and Domestic Service: The Politics of Black Women in Italy. Aldershot: Ashgate.

Ardrey IV, W. J., Pecotich, A., and Shultz, C. J. II. (2006). Entrepreneurial women as catalysts for socioeconomic development in transitioning Cambodia, Laos, and Vietnam. Consumption, Markets \& Culture, 9(4), 277-300.

Binger, A. (2004). The poverty reduction challenge in LCDs. CDP Background Paper No. 3 United Nations Policy and Analysis Division, Department of Economic and Social Affairs. Retrieved from 
http://www.un.org/en/development/desa/policy/cdp/cdp_background_papers/bp2004_3.p df.

Bonfiglioli, C. (2015). Gendered citizenship in the global European periphery: textile workers in post-Yugoslav states. Women's Studies International Forum, 49, 57-65.

Central Intelligence Agency (2017). Croatia. The World Factbook. Retrieved from https://www.cia.gov/library/publications/the-world-factbook/geos/hr.html.

Centre for Women's Studies Zagreb (Producer), and Iveković, S. (Director) (2002). Pine and Fir Trees. [DVD.] Zagreb, Croatia: Centre for Women's Studies Zagreb \& Women's Art Center \& Elektra, Top Mag d.o.o. in cooperation with Slovenska kinoteka.

Chou, M. H. (2012). EU mobility partnerships and gender: origin and implications. In R. Sollund (ed.) Transnational Migration, Gender and Rights. Bingley: Emerald Publishing Limited, pp. 11-31.

Cockburn, C. (1998). The Space Between Us: Negotiating Gender and National Identities in Conflict. New York: Zed Books.

Coulter, R. A., Price, L. L., and Feick, L. F. (2003). Rethinking the origins of involvement and brand commitment: insights from postsocialist Central Europe. Journal of Consumer Research, 30, 151-169.

Croatian Bureau of Statistics (2017). Migration of population of Republic of Croatia, 2016. Retrieved from https://www.dzs.hr/default_e.htm.

Crockett, D., Downey, H., Firat, A. F., Ozanne, J. L., and Pettigrew, S. (2013). Conceptualizing a transformative research agenda. Journal of Business Research, 66(8), 1171-1178.

Despot, B. (1981). Žena i samoupravljanje [Women and Self-management]. Delo, XXVII(4), 112-116. 
Drakulić, S. (1992), How We Survived Communism and Even Laughed. New York: HarperPerennial.

Einhorn, B. (1993). Cinderella Goes to Market: Citizenship, Gender, and Women's Movements in East Central Europe. London: Verso.

Friedan, B. (1963). The Feminine Mystique. New York: W.W. Norton and Co.

Funk, N. (2004). Feminist critiques of Liberalism: can they travel east? Their relevance in Eastern and Central Europe and the Former Soviet Union. Signs, 29(3), 695-729.

Ghodsee, K. (2004). Feminism-by-design: emerging capitalisms, cultural feminism, and women's nongovernmental organizations in postsocialist Eastern Europe. Signs, 29(3), $727-753$.

Gopaldas, A. (2013). Intersectionality 101. Journal of Public Policy \& Marketing, 32(Special Issue), 90-94.

Grewal, I., and Kaplan, C. (1994). Scattered Hegemonies: Postmodernity and Transnational Feminist Practices. Minneapolis, MN: University of Minnesota Press.

Hein, W., Steinfield, L., Ourahmoune, N., Coleman, C.A., Zayer, L.T., and Littlefield, J. (2016). Gender justice and the market: a transformative consumer research perspective. Journal of Public Policy \& Marketing, 35(2), 223-236.

Leinert Novosel, S. (1999). Women on the Threshold of the 21st Century: Between Motherhood and Professions. Zagreb: TOD Women's Group, EDAC.

Luthar, B., and Pušnik, M. (eds.) (2010). Remembering Utopia: The Culture of Everyday Life in Socialist Yugoslavia. Washington, DC: New Academia Publishing, LLC.

Mick, D. G., Pettigrew, S., Pechmann, C., and Ozanne, J. L. (eds.) (2012). Transformative Consumer Research for Personal and Collective Well-Being. New York: Routledge. 
Moghadam, V. M. (2005). Globalizing Women: Transnational Feminist Networks. Baltimore, MD: Johns Hopkins University Press.

Morgan, R. (1984). Sisterhood is Global: The International Women's Movement Anthology, 1st ed. Garden City, NY: Anchor Press/Doubleday.

Nadkarni, A. (2017). Transnational Feminism. In Oxford Bibliographies (Literary and Critical Theory). Retrieved from http://www.oxfordbibliographies.com/view/document/obo9780190221911/obo-9780190221911-0006.xml. doi: 10.1093/OBO/97801902219110006.

Nikolić-Ristanović, V. (2000). Women, Violence, and War: Wartime Victimization of Refugees in the Balkans. Budapest: Central European University Press.

Pavlovič, T. (1999). Women in Croatia: feminists, nationalists, and homosexuals. In Sabrina P. Ramet (ed.) Gender and Politics in the Western Balkans. University Park, PA: The Pennsylvania State University Press, pp. 131-152.

Rihtman-Auguštin, D. (1980). Moć žene u patrijarhalnoj i suvremenoj kulturi [The power of women in patriarchal and contemporary culture]. Žena, 4-5, 83-85.

Špehar, A. (2012). This far, but no further? Benefits and limitations of EU gender equality policy making in the Western Balkans. East European Politics and Societies, 26(2), 362-379. https://doi.org/10.1177/0888325411429742.

Sredl, K. (2007). Consumption and class during and after state socialism: research in consumer behavior. In R. Belk, and J. Sherry (eds.) Consumer Culture Theory. Oxford: Elsevier, pp. 187-205. 
Sredl, K. C. (2018). Gendered market subjectivity: autonomy, privilege, and emotional subjectivity in normalizing post-socialist neoliberal ideology. Consumption Markets \& Culture, 21(6), 532-553.

Sredl, K., and Renko, N. (2009). Women's possessions and social class in contemporary Zagreb, Društvena istraživanja. Journal for General Social Issues, 18(3), 565-581.

SG FNRJ (1955). Statistički godišnjak FRNJ 1955. Beograd: Federativna Narodna Republika Jugoslavija, Savezni zavod za statistiku. Statistical Yearbook of the FRNJ 1995. Belgrade: Socialist Federal Republic of Yugoslavia, Federal Statistical Office.

Suchland, J. (2011). Is postsocialism transnational? Signs, 36(4), 837-862. https://doi.org/10.1086/658899.

Svanberg, J. (2011). Labour migration and the Swedish labour market model: a case study of recruitment of Yugoslav workers to Svenska Flaktfabriken in Vaxjo, 1969-1970. Scandinavian Journal of History, 36(1), 91-113. https://doi.org/10.1080/03468755.2010.540702.

Trimberger, E. K. (1986). [Review of the book Sisterhood is Global: The International Women's Movement Anthology, by R. Morgan.] Contemporary Sociology, 15(1), 106-107. https://doi.org/10.2307/2070954.

United National Development Programme (2016). Human Development Reports. Retrieved from http://hdr.undp.org/en/composite/GII.

United Nations Development Programme (2017). 20 Years of Partnership. Retrieved from http://www.hr.undp.org/content/croatia/en/home/temporary-homepage.html. United Nations Development Programme (2018). Georgia. Retrieved from http://www.ge.undp.org/. 
United Nations Economic Analysis and Policy Division (2018). LCDs at a Glance. Retrieved from https://www.un.org/development/desa/dpad/least-developed-country-category/ldcsat-a-glance.html.

Wilson, E. (1986). [Review of the book Sisterhood Is Global: The International Women's Movement Anthology, by R. Morgan.] Signs, 11(2), 390-392.

Woodward, S. L. (1995). Socialist Unemployment: The Political Economy of Yugoslavia 19451990. Princeton, NJ: Princeton University Press.

Zaharijević, A. (2015). Dissidents, disloyal citizens and partisans of emancipation: feminist citizenship in Yugoslavia and post-Yugoslav spaces. Women's Studies International Forum, 49, 93-100. https://doi.org/10.1016/j.wsif.2014.07.002. 